\title{
A novel sulfonamide agent, MPSP-001, exhibits potent activity against human cancer cells in vitro through disruption of microtubule
}

\author{
Zu-long LIU ${ }^{1}$, Wei TIAN², Yong WANG ${ }^{3}$, Shan $\mathrm{KUANG}^{1}$, Xiao-min $\mathrm{LUO}^{3}$, Qiang YU ${ }^{1,}$ * \\ ${ }^{1}$ Division of Anti-Tumor Pharmacology, Shanghai Institute of Materia Medica, Chinese Academy of Sciences, Shanghai 201203, China; \\ ${ }^{2}$ The School of Life Science and Biopharmaceutics of Shenyang Pharmaceutical University, Shenyang 110016, China; ${ }^{3}$ Drug Discovery \\ and Design Center, Shanghai, Institute of Materia Medica, Chinese Academy of Sciences, Shanghai 201203, China
}

\begin{abstract}
Aim: To evaluate the anti-cancer effects of a new sulfonamide derivative, 2-(N-(3-chlorophenyl)-4-methoxyphenylsulfonamido)-N-hydroxypropanamide (MPSP-001).

Methods: Human cancer cell lines (HepG2, THP-1, K562, HGC-27, SKOV3, PANC-1, SW480, Kba, HeLa, A549, MDA-MB-453, and MCF7 ) were examined. The cytotoxicity of MPSP-001 was evaluated using the WST-8 assay. Cell cycle distribution was examined with flow cytometry. Mitotic spindle formation was detected using immunofluorescence microscopy. Apoptosis-related proteins were examined with Western blot using specific phosphorylated protein antibodies. Competitive tubulin-binding assay was performed to test whether the compound competitively bound to the colchicine site. Molecular docking was performed to explore the possible binding conformation.

Results: MPSP-001 potently inhibited the growth of the 12 different types of human cancer cells with the $\mathrm{IC}_{50}$ values ranging from 1.9 to $15.7 \mu \mathrm{mol} / \mathrm{L}$. The compound exerted potent inhibition on the drug-resistant Kb/VCR and MCF-7/ADR cells, as on Kba and MCF-7 cells. In HeLa, HGC-27, A549, and other cells, the compound ( $5 \mu \mathrm{mol} / \mathrm{L}$ ) caused cell cycle arrest at the $\mathrm{G}_{2} / \mathrm{M}$ phase, and subsequently induced cell apoptosis. In Hela cells, it prevented the mitotic spindle formation. Furthermore, the compound dose-dependently inhibited polymerization of tubulin in vitro, and directly bound to the colchicine-site of $\beta$-tubulin. Molecular docking predicted that the compound may form two hydrogen bonds to the binding pocket. The compound showed synergistic effects with colchicine and taxol in blocking mitosis of HeLa cells.
\end{abstract}

Conclusion: MPSP-001 shows a broad-spectrum of anti-tumor efficacy in vitro and represents a novel structure with anti-microtubule activity.

Keywords: MPSP-001; sulfonamide; anticancer drug; microtubules; tubulin; mitotic spindle; drug resistance; drug synergism

Acta Pharmacologica Sinica (2012) 33: 261-270; doi: 10.1038/aps.2011.156

\section{Introduction}

Cancer chemotherapy has achieved significant success in the discovery of new drugs ${ }^{[1]}$. One of the most successful classes of antitumor drugs targets microtubules, the principal components of the cytoskeleton which is important in cell division, organelle transports, cytokinesis, maintenance of cell morphology and signal transduction ${ }^{[2]}$. The essential role of microtubules in mitosis and cell division makes them and their regulatory proteins important, and perhaps the best, targets for anticancer drugs ${ }^{[3,4]}$. There are two categories of anti-microtubule compounds used to target highly proliferating malignant cells.

\footnotetext{
* To whom correspondence should be addressed.

E-mail qyu@sibs.ac.cn

Received 2011-05-18 Accepted 2011-10-20
}

One is microtubule depolymerizing agents such as colchicinoids and vinca alkaloids which inhibit tubulin polymerization $^{[5]}$. The other one is microtubule polymerizing agents such as taxanes and epothilones which promote or stabilize the formation of tubulin polymer ${ }^{[6]}$. The anti-microtubule agents are also classified based on their binding sites on tubulin ${ }^{[7]}$. Recent studies suggest that the inhibitory effects of these drugs are due to their interruption of microtubule dynamics rather than to alternate the microtubule polymer mass ${ }^{[8]}$. The disruption of microtubule dynamics leads to the arrest of growing cells in metaphase/anaphase, causing apoptotic or non-apoptotic cell death. Although all of the anti-microtubule agents effectively inhibit microtubule dynamics in vitro, their effects against different types of cancers vary in vivo ${ }^{[9]}$. In addition, despite the success of taxanes and vinca alkaloids to inhibit the progres- 
sion of some cancers in clinical use, resistance to anti-microtubule agents encounter in many tumor types, particularly after multiple cycles of therapy ${ }^{[10,11]}$. Therefore, there has been great interest in identifying and developing novel anti-microtubule drugs.

Sulfonamides have been in clinical use for several decades. Sulfonamides have antibacterial, diuretic, antidiabetic, antithyroid, antihypertensive and antiviral activities ${ }^{[12]}$. Recently, many novel sulfonamide derivatives have shown substantial antitumor activities ${ }^{[13,14]}$. For instance, E7070 and E7010 are regarded as breakthroughs in the discovery of new sulfonamides with strong antineoplastic abilities. E7070 belongs to a class of novel cell cycle inhibitors that block cell cycle progression at multiple points, although its target remains unclear $^{[15-18]}$. E7010 reversibly binds to the colchicine-binding site of tubulin and arrests cells in the mitotic phase ${ }^{[19-21]}$. Both E7010 and E7070 display antitumor activity against rodent and human tumor xenografts and are currently undergoing phase I/II clinical trials ${ }^{[15,16,20,22]}$. Another sulfonamide, HMN-214, arrests cells in $\mathrm{G}_{2} / \mathrm{M}$ phase and exhibits antitumor activity. This antitumor activity is mediated by cytotoxicity, via inhibiting polo-like kinase, and by down-regulation of MDR1 via binding to the B-subunit of the essential transcription factor NF- $Y^{[23-25]}$.

Here we report our discovery of a new benzenesulfonamide, MPSP-001, and study for its ability to inhibit tumor cell growth. We found that MPSP-001 had strong antiproliferative activity against human tumor cell lines, as well as the ability to overcome drug resistance. Analysis of the function and mechanism of MPSP-001 revealed that MPSP-001 is a microtubuledestabilizing agent. It inhibits microtubule polymerization, arrests cells at early stage of mitosis and induces apoptosis. Our data suggests that MPSP-001 is a novel anti-microtubule compound. Understanding the mechanism of MPSP-001 will increase our knowledge about anti-microtubule agents and help us to design other better benzenesulfonamide drugs with anti-cancer activity.

\section{Materials and methods}

\section{Synthesis of compound MPSP-001}

MPSP-001 was synthesized through a five-step synthetic route, starting from the commercially available 4-methoxybenzenesulfonyl chloride (a) and 3-chlorobenzeneamine (b). N-(3-chlorophenyl)-4-methoxybenzenesulfonamide(c) was synthesized from a and $b$, and reacted with ethyl DL-2bromopropionate to give methyl 2-(N-(3-chlorophenyl)-4methoxyphenylsulfonamido) propanoate (e). After hydrolyzation, condensation, the final product was synthesized in $20 \%$ yield and characterized by ${ }^{1} \mathrm{HNMR}$, MS, and elemental analyses. ${ }^{1} \mathrm{HNMR}\left(400 \mathrm{MHz}, \mathrm{CDCl}_{3}\right) \delta=9.39$ (br·s, $\left.1 \mathrm{H}, \mathrm{NH}\right)$, 7.63 (d, J=8.2 Hz, 2H, ArH), 7.35 (d, J=8.3 Hz, 1H, ArH), 7.25 (dd, J=8.3, 7.6 Hz, 1H, ArH), 7.12 (s, 1H, ArH), 7.04 (d, J=7.6 $\mathrm{Hz}, 1 \mathrm{H}, \mathrm{ArH}), 6.96$ (d, J=8.1 Hz, 2H, ArH), 4.79 (s, 1H, CH), 3.89 (s, 3H, $\left.\mathrm{OCH}_{3}\right), 1.15\left(\mathrm{~d}, \mathrm{~J}=6.3,3 \mathrm{H}, \mathrm{CH}_{3}\right)$ ppm. MS (ESI): $m / z=385[\mathrm{M}+\mathrm{H}]^{+}$. Anal Calcd for $\mathrm{C}_{16} \mathrm{H}_{17} \mathrm{ClN}_{2} \mathrm{O}_{5} \mathrm{~S}: \mathrm{C}, 49.94 ; \mathrm{H}$, 4.45; N, 7.28; S, 8.33. Found: C, 49.90; H, 4.44; N, 7.30; S, 8.36.
The purity of MPSP-001 was not less than 95\% (Radiochemical Purity, HPLC).

\section{Chemicals and antibodies}

Colchicine (COL), paclitaxel (Taxol), vincristin (VCR) and Adriamycin (ADR) were purchased from Sigma Chemical Co. Antibodies were obtained from following companies: poly(ADP-ribose) polymerase (PARP) (Cell Signalling Technology); a-tubulin, horseradish peroxidase (HRP)-conjugated secondary antibody (Santa Cruz Biotechnology); and fluorescent isothiocyanate (FITC)-conjugated secondary antibody (Ancell Corporation). Medium and reagents of cell culture were acquired from Invitrogen. All other chemicals were purchased from Sigma Chemical Co.

\section{Cell culture and reagents}

Human cancer cell lines (HepG2, THP-1, K562, HGC-27, SKOV3, PANC-1, SW480, HeLa, A549, and MDA-MB-453) used in this study were procured from American Type Culture Collection. Resistant cell lines KB/VCR, MCF-7/ADR, and their parental cells were provided by Professor Jian DING from Shanghai Institute of Materia Medica, Chinese Academy of Sciences. K562, THP-1, and A549 cells were grown in RPMI -1640 medium supplemented with $10 \%$ fetal bovine serum (FBS); MCF-7, HepG2, HGC-27, SKOV3, PANC-1, SW480, HeLa, and MDA-MB-453 cells were cultured in Dulbecco's modified Eagle's medium supplemented with 10\% FBS. KB and KB/VCR were grown in Minimum Essential Medium Eagle's (MEM) medium and supplemented with 10\% FBS, 2 $\mathrm{mmol} / \mathrm{L}$ glutamine and $1 \mathrm{mmol} / \mathrm{L}$ pyruvic acid; MCF-7/ADR cells were cultured in MEM medium and supplemented with $10 \%$ FBS, $1 \mathrm{mmol} / \mathrm{L}$ pyruvic acid and $0.01 \mathrm{mg} / \mathrm{mL}$ insulin. All resistant cell lines were incubated in the drug-free medium for 3 days before harvesting for the growth inhibition assay.

\section{Cytotoxicity assay}

In vitro growth inhibition was assessed with the WST-8 assay $^{[26]}$. Exponentially growing cells were seeded into 96-well plate at a density of 3000 to 10000 cells/well (depending on the doubling time of the cell lines) and cultured overnight. Then cells were treated with various concentrations of drugs and incubated for additional $48 \mathrm{~h}$. A tetrazolium salt (WST-8) was added at the last $2 \mathrm{~h}$ before the end of culture. After continuous incubation for $2 \mathrm{~h}$, the absorbance was measured by a microplate reader at a wavelength of $450 \mathrm{~nm}$. The values shown as the means and SD of at least three independent experiments performed in duplicates.

\section{Flow cytometry analysis}

The cells were harvested and washed with PBS, resuspended in $1 \mathrm{~mL}$ of ice-cold $75 \%$ ethanol. After being left to stand overnight, cell pellets were collected by centrifugation, resuspended in $500 \mu \mathrm{L}$ of hypotonic buffer $(0.5 \%$ Triton $\mathrm{X}-100$ in PBS and $0.5 \mu \mathrm{g} / \mathrm{mL}$ RNase), and incubated at $37^{\circ} \mathrm{C}$ for $30 \mathrm{~min}$. Then $25 \mu \mathrm{L}$ of propidium iodide solution $(50 \mu \mathrm{g} / \mathrm{mL})$ was added, and the mixture was allowed to stand on ice for $1 \mathrm{~h}$. 
Fluorescence emitted from the propidium iodide-DNA complex was quantitated after excitation of the fluorescent dye by FAC-Scan cytometry. The histogram of DNA distribution was modeled as a sum of $G_{1}, G_{2} / M, S$ phase, and a sub- $G_{1}$ population, by using ModFitLT software.

\section{Immunofluorescence microscopy}

After culturing for $48 \mathrm{~h}$ on coverslips, HeLa cells were incubated with drugs at various concentrations for $16 \mathrm{~h}$. Cells were then fixed. After being blocked, cells were incubated with mouse monoclonal a-tubulin antibody for $2 \mathrm{~h}$ at $37^{\circ} \mathrm{C}$. The secondary antibody, fluorescein (FITC)-conjugated affinity goat anti-mouse IgG $(\mathrm{H}+\mathrm{L})$, was added and incubated for $1 \mathrm{~h}$. Chromosomes were stained with $1 \mu \mathrm{g} / \mathrm{mL}$ DAPI in PBS. After washing with PBS, the slides were mounted and sealed. Fluorescence images were captured by using Leica TCS SP2 laser confocal microscope.

\section{Western blot analysis}

Cells were lysed in the ice-cold cell lysis buffer ( $\mathrm{pH} 7.6)$ containing $0.5 \mathrm{mmol} / \mathrm{L}$ dithiothreitol, $0.2 \mathrm{mmol} / \mathrm{L}$ EDTA, 20 $\mathrm{mmol} / \mathrm{L}$ HEPES, $2.5 \mathrm{mmol} / \mathrm{L} \mathrm{MgCl}_{2}, 75 \mathrm{mmol} / \mathrm{L} \mathrm{NaCl}, 0.1$ $\mathrm{mmol} / \mathrm{L} \mathrm{Na}_{3} \mathrm{VO}_{4}, 50 \mathrm{mmol} / \mathrm{L} \mathrm{NaF}$, and $0.1 \%$ Triton X-100. The protease inhibitors including $1 \mu \mathrm{g} / \mathrm{mL}$ aprotinin, 0.5 $\mu \mathrm{g} / \mathrm{mL}$ leupeptin, and $100 \mu \mathrm{g} / \mathrm{mL}$ 4-(2-aminoethyl)-benzenesulfonyl fluoride were added to the cell suspension. The cell extracts were gently rotated at $4{ }^{\circ} \mathrm{C}$ for $30 \mathrm{~min}$. After centrifugation, the pellets were discarded. Equal amounts of proteins were subjected to $8 \%-10 \%$ SDS-PAGE. After transfered onto nitrocellulose membranes, the proteins were hybridized with various antibodies according to the instructions provided by the manufacturers.

\section{In vitro tubulin polymerization assay}

The assay was essentially performed according to Kuo et al ${ }^{[27]}$. Briefly, the sample ( $100 \mu \mathrm{L}$ of $3 \mathrm{mg} / \mathrm{mL}$ tubulin proteins) in TP buffer (100 mmol/L PIPES, pH 6.9, 2 mmol/ $\mathrm{L} \mathrm{MgCl}_{2}$, $1 \mathrm{mmol} / \mathrm{L}$ GTP, and 15\% glycerol) was placed in 96-well microtiter plates in the presence of test agents. Mixtures were warmed to $37^{\circ} \mathrm{C}$ and the increase in absorbance was measured at $340 \mathrm{~nm}$ in TECAN Genois Pro Microplate Reader and recorded every $30 \mathrm{~s}$ for $1 \mathrm{~h}$.

\section{Competitive tubulin-binding assay}

For colchicine competitive binding assay, tubulin was coincubated with indicated concentrations of MPSP-001 and vincristine at $37^{\circ} \mathrm{C}$ for $1 \mathrm{~h}$. Then colchicine was added to a final concentration of $5 \mu \mathrm{mol} / \mathrm{L}$. Fluorescence was determined using a Hitachi F-2500 spectrofluorometer (Tokyo, Japan) at excitation wavelengths of $365 \mathrm{~nm}$ and emission wavelengths of $435 \mathrm{~nm}$. Blank values (buffer alone) as background were subtracted from all samples. Then the inhibition rate (IR) was calculated as follows: IR=F/F0 where F0 is the fluorescence of the $5 \mathrm{\mu mol} / \mathrm{L}$ colchicine-tubulin complex, and $\mathrm{F}$ is the fluorescence of a given concentration of MPSP-001 or vincristine (12.5 $\mu \mathrm{mol} / \mathrm{L}, 25 \mu \mathrm{mol} / \mathrm{L}, 50 \mu \mathrm{mol} / \mathrm{L}$ and $100 \mu \mathrm{mol} / \mathrm{L})$ competition with the $5 \mu \mathrm{mol} / \mathrm{L}$ colchicine-tubulin complex. Vincristine, not binding in the colchicine-site of tubulin, was added as a negative control ${ }^{[28]}$.

\section{Molecular modeling}

The X-ray crystal structure of $\alpha, \beta$-tubulin complexed with $\mathrm{N}$-deacetyl-N-(2-mercaptoacetyl)-colchicine (DAMA-colchicine) was obtained from the Brookhaven Protein Data Bank (entry code: $1 S A 0^{[29]}$ ) as the target structures in the molecular docking. Compounds were docked into the colchicine binding site using Autodock 4.00 ${ }^{[30]}$. For each compound, 30 docking runs were performed and the conformation with the lowest binding free energy was selected as the possible binding conformation.

\section{Analysis of drug synergism}

The Combination Index (CI) was calculated to determine whether the drugs interacted synergistically, additively, or antagonistically ${ }^{[31]}$. The CI is calculated by the following equation: $\mathrm{CI}=\mathrm{D}_{1} /(\mathrm{Dm})_{1}+\mathrm{D}_{2} /(\mathrm{Dm})_{2}+\mathrm{D}_{1} \times \mathrm{D}_{2} /\left[(\mathrm{Dm})_{1} \times(\mathrm{Dm})_{2}\right]$, in which $\mathrm{D}_{1}$ is the concentration of a drug necessary to achieve a particular effect in the combination; $(\mathrm{Dm})_{1}$ is the concentration of the same drug that will produce the identical level of effect by itself; $D_{2}$ is the concentration of the second drug that will produce a particular effect in the combination; and $(\mathrm{Dm})_{2}$ is the concentration of the second drug, which will produce the same level of effect by itself. CI $>1$ indicates antagonism, $\mathrm{CI}<1$ indicates synergy, and $\mathrm{CI}=1$ indicates additivity ${ }^{[32]}$. Two independent experiments were performed to obtain the CI. The representative data were shown in Table 2.

\section{Statistical analysis}

Unless stated otherwise, experiments were run in triplicate and results were compared in Excel by two-tailed unpaired t-test. In the case of the effects analysis of MPSP-001 on the aberrant mitotic spindle, the statistical analysis of incidence rates of non-bipoles and chromosome misalignment were used to determine significance ${ }^{[33]}$.

\section{Results}

\section{MPSP-001 inhibited growth of various human tumor cells}

MPSP-001 is a novel sulfonamide agent and its chemical formula is $\mathrm{C}_{16} \mathrm{H}_{17} \mathrm{C}_{1} \mathrm{~N}_{2} \mathrm{O}_{5} \mathrm{~S}$ yielding a molecular weight of 384.83 (Figure 1). We used the WST-8 assay to evaluate the antiproliferative effect of MPSP-001 on several representative human tumor cell lines: hepatocellular carcinoma (HepG2), leukemia (THP-1 and K562), gastric carcinoma (HGC-27), ovarian carci-

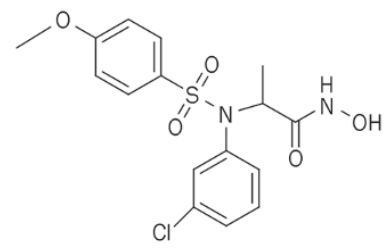

Figure 1. Chemical structure of MPSP-001. 
noma (SKOV3), pancreatic carcinoma (PANC-1), colon adenocarcinoma (SW480), cervical carcinoma (KB and HeLa), lung adenocarcinoma (A549), and breast carcinoma (MDA-MB-453 and MCF-7). MPSP-001 inhibited the growth of all of the cancer cell lines that we tested with $\mathrm{IC}_{50}$ values ranging from 1.9 to $15.7 \mu \mathrm{mol} / \mathrm{L}$ (Table 1). Among the 10 solid tumor cell lines we analyzed, HeLa cell was the most sensitive cell line with an $\mathrm{IC}_{50}$ value about $8.1 \mu \mathrm{mol} / \mathrm{L}$. We therefore used HeLa cells as a model cell in the following experiments.

Table 1. Growth inhibition of MPSP-001 against various human cancer cell lines.

\begin{tabular}{llr}
\hline \multicolumn{1}{c}{ Origin } & Cell lines & $\mathrm{IC}_{50}(\mu \mathrm{mol} / \mathrm{L})$ \\
\hline Hepatocellular carcinoma & HepG2 & $9.1 \pm 4.2$ \\
Acute monocytic leukemia & THP-1 & $1.9 \pm 1.2$ \\
Chronic myelogenous leukemia & K562 & $6.9 \pm 3.9$ \\
Gastric carcinoma & HGC-27 & $15.7 \pm 2.6$ \\
Ovarian carcinoma & SKOV3 & $11.6 \pm 4.1$ \\
Pancreatic carcinoma & PANC-1 & $15.4 \pm 6.6$ \\
Colon adenocarcinoma & SW480 & $15.1 \pm 3.5$ \\
Cervical carcinoma & Kb & $8.4 \pm 2.9$ \\
Cervical carcinoma & HeLa & $8.1 \pm 3.3$ \\
Lung adenocarcinoma & A549 & $15.0 \pm 5.8$ \\
Breast carcinoma & MDA-MB-453 & $14.8 \pm 4.5$ \\
Breast adenocarcinoma & MCF-7 & $12.4 \pm 2.7$ \\
\hline
\end{tabular}

Each value represents the mean $\pm S D$ of three independent experiments. ${ }^{a}$ The KB cell line was originally derived from an epidermal carcinoma of the mouth but has now been shown to have HeLa characteristics.

MPSP-001 caused cell cycle arrest at the $G_{2} / M$ phase and subsequently induced cell apoptosis.

We first analyzed the effects of MPSP-001 on cell cycle $\mathrm{e}^{[34]}$. MPSP-001 induced a dose-dependent $\mathrm{G}_{2} / \mathrm{M}$ arrest after $16 \mathrm{~h}$ of drug exposure. When exposed to $10 \mu \mathrm{mol} / \mathrm{L}$ MPSP-001 for $16 \mathrm{~h}, 80.11 \%$ of the cell population was blocked in $\mathrm{G}_{2} / \mathrm{M}$ phase (Figure 2A). Similarly, MPSP-001 induced a timedependent $\mathrm{G}_{2} / \mathrm{M}$ arrest after different time of drug exposure. When exposed to $5 \mu \mathrm{mol} / \mathrm{L}$ MPSP-001 for $4,8,16 \mathrm{~h}$, the cell population of HeLa cells in $\mathrm{G}_{2} / \mathrm{M}$ phase was $33.74 \%$, $46.27 \%$, and $78.80 \%$, respectively (Figure $2 \mathrm{~B}$ ). We further analyzed the effects of MPSP-001 on HGC-27, A549, and other cells, similar results were observed (data not shown). These data clearly indicated that MPSP-001 was a mitotic blocker.

We next analyzed the effects of MPSP-001 on cell death. The apoptosis, as indicated by the cleavage of PARP, occurred $16 \mathrm{~h}$ after the MPSP-001 treatment (Figure 3C).

\section{MPSP-001 disrupted mitotic spindle in cells}

Most of the anti-mitotic agents affect microtubules ${ }^{[35]}$. So the effects of MPSP-001 on microtubule structure were then examined by immuno-fluorescence microscopy using a-tubulin antibody. Normal control cells in metaphase displayed a bipo- lar mitotic spindle (Figure 3Ad). Cells exposed to $5 \mu \mathrm{mol} / \mathrm{L}$ MPSP-001 for $16 \mathrm{~h}$ displayed disrupted mitotic spindles and chromosome misalignment (Figure 3Ae-3Ah). Examples of spindle damage including non-bipoles (apolar metaphase, monopolar metaphase, tripolar metaphase and mutipolar metaphase) and chromosome misalignment. A typical example of a tripolar prometaphase was shown in Figure 3Af. Figure $3 \mathrm{Ag}$ exemplified a mutipolar metaphase. An example of bipolar metaphase with chromosome misalignment was seen in Figure 3Ah. We counted the number of cells with disrupted mitotic spindles. Among 150 randomly selected cells in the mitotic phase not treated with MPSP-001, there were 2 non-bipolar metaphase cells and 1 chromosome misalignment cell. In comparison, in the randomly selected mitotic cells treated with MPSP-001, there were 39 and 27, respectively. These data showed that the rates of mitotic spindle disruption were significantly different between the MPSP-001 exposed group and non-exposed group (Figure 3B).

To compare the effects of MPSP-001 with other mitotic blockers, we studied the morphological changes of tubulin in interphase HeLa cells after exposure to the various drugs. Cells were treated with $250 \mathrm{nmol} / \mathrm{L}$ Taxol, $100 \mathrm{nmol} / \mathrm{L}$ colchicine, $100 \mathrm{nmol} / \mathrm{L}$ vincristine, and $5 \mu \mathrm{mol} / \mathrm{L}$ MPSP-001 respectively for $16 \mathrm{~h}$. Taxol, a microtubule-stabilizing agent, caused an increase in density of cellular microtubules (Figure $3 \mathrm{Cb}$, $3 \mathrm{Cg}$ ). In contrast, colchicine and vincristine, two microtubule depolymerizing agents, caused microtubule depolymerization with short microtubules in the cytoplasm (Figure 3Cc, 3Cd, 3Ch, 3Ci). MPSP-001 (Figure 3Ce, 3Cj) also caused similar morphological changes of microtubules to that of colchicine and vincristine, suggesting that MPSP-001 may be a microtubule depolymerizing agent.

\section{MPSP-001 inhibited in vitro microtubule assembly and directly bind to colchicine-binding site on tubulin}

To confirm the above observations, we investigated the effect of MPSP-001 on tubulin polymerization using an in vitro tubulin polymerization assay (Figure 4A). MPSP-001 inhibited polymerization of tubulin in a dose-dependent manner similar to that of colchicine and vincristine.

Two known sulfonamide agents, E7010, and HMN-214, all bind to the colchicine site of tubulin. Therefore we further assessed the ability of MPSP-001 to compete with colchicine for binding to tubulin via competitive binding assays. Because the intrinsic fluorescence of colchicine increases upon binding to tubulin ${ }^{[36]}$, it was used as an index for MPSP-001 competition with colchicine in tubulin binding. As shown in Figure $4 \mathrm{~B}$, vincristine did not affect the binding to tubulin. However, the fluorescence of colchicine-tubulin complex was reduced in the presence of MPSP-001 in a dose-dependent manner, suggesting that MPSP-001 were competing with colchicine to bind to tubulin.

Molecular docking predicted the interaction model of MPSP-001 binding to the colchicine site of $\beta$-tubulin (Figure $4 \mathrm{C}, 4 \mathrm{D})$. In the docked complex, compound MPSP-001 bound to $\alpha, \beta$-tubulin in an extended conformation and the calculated 
A

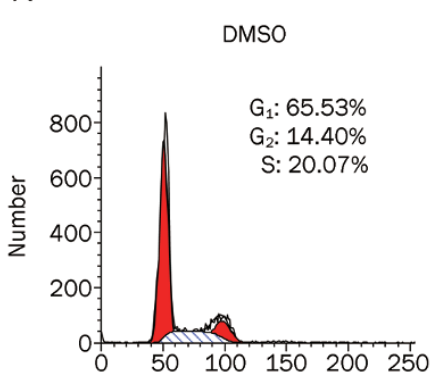

MPSP-001, $16 \mathrm{~h}$

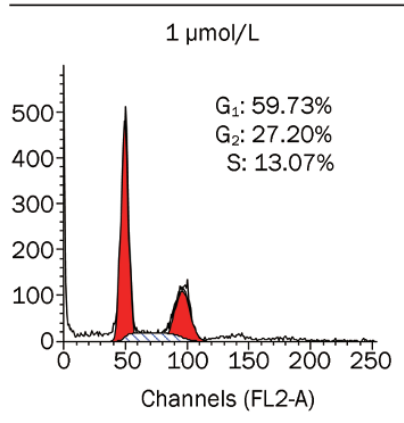

$8 \mathrm{~h}$
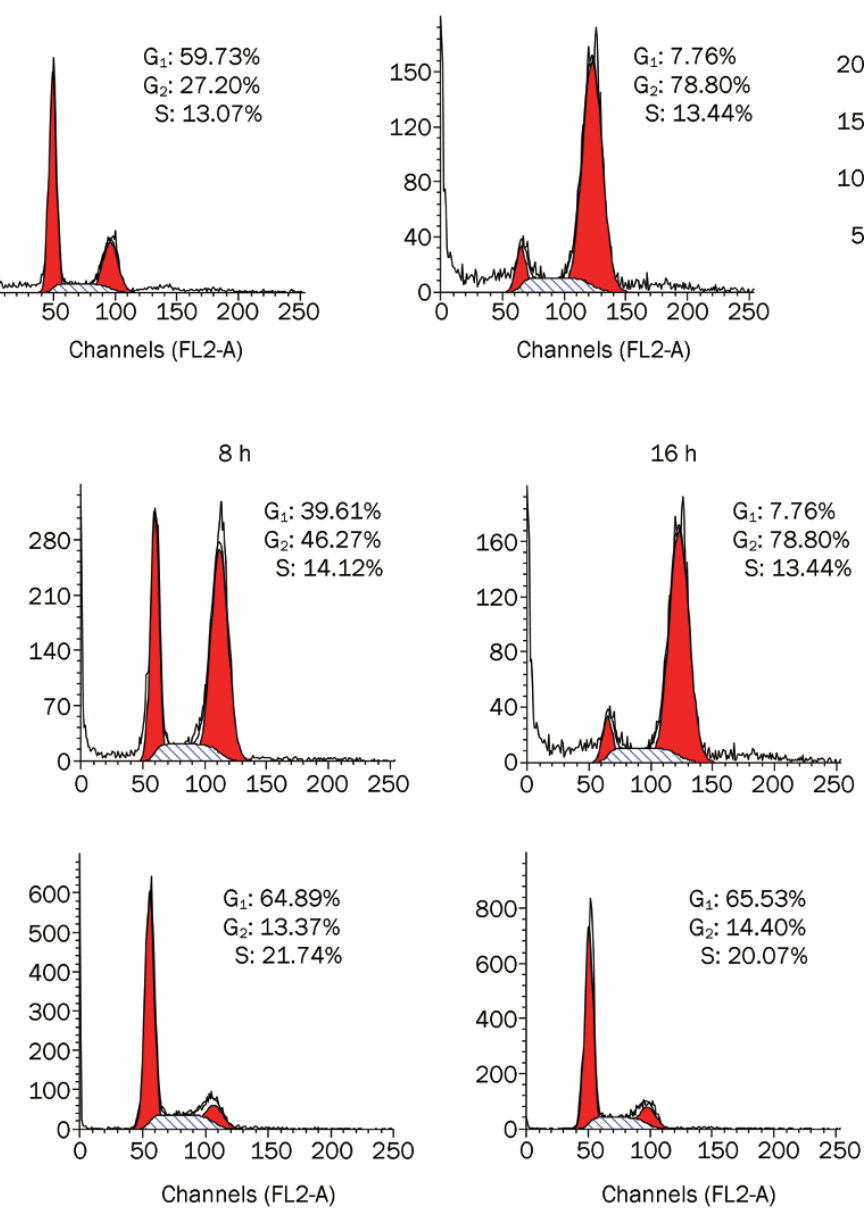

C

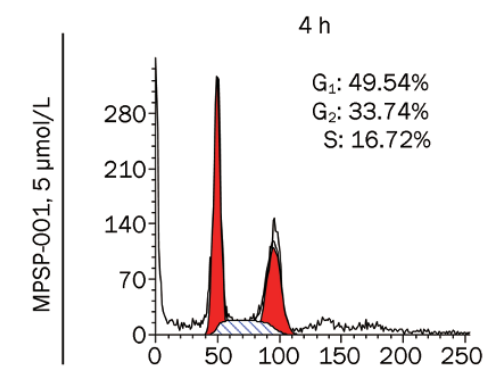

$10 \mu \mathrm{mol} / \mathrm{L}$
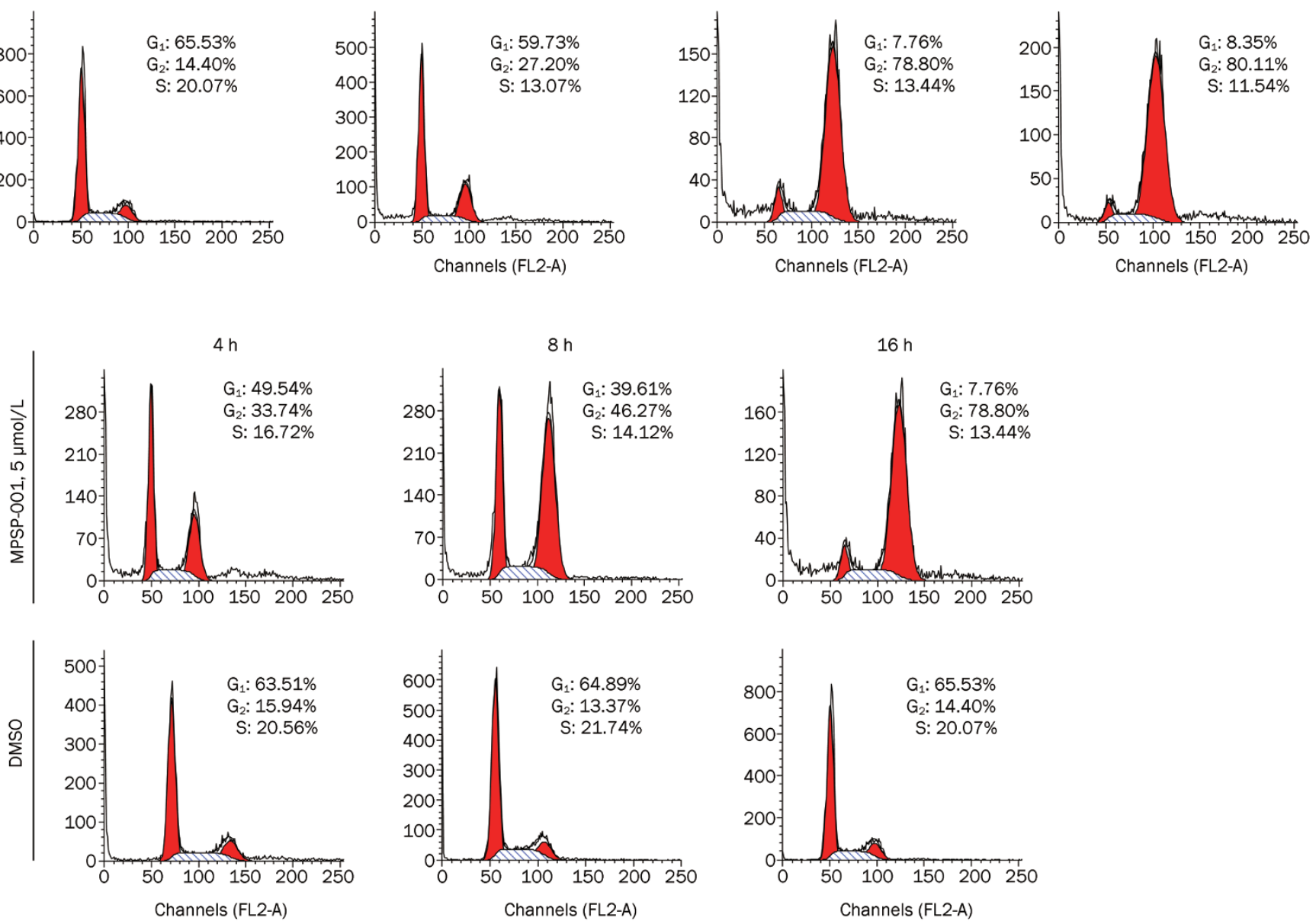

.

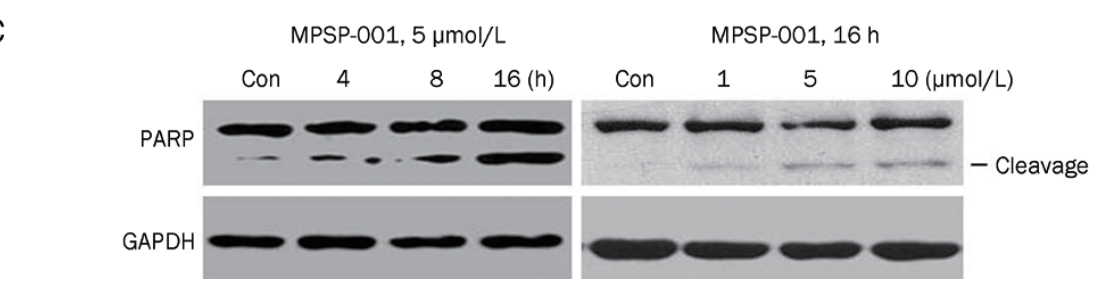

Figure 2. Effects of MPSP-001 on cell cycle distribution and cell death. (A) The concentration effects of MPSP-001 on cell cycle progression of HeLa cells. HeLa cells were treated with different concentrations of MPSP-001 for $16 \mathrm{~h}$. Then, the cells were fixed and stained with PI and analyzed by flow cytometry. Percentages of cells in different phases were shown. The data are representative of three independent experiments. (B) The time effects of MPSP-001 on cell cycle progressions of HeLa cells. HeLa cells were treated with $5 \mu \mathrm{mol} / \mathrm{L}$ MPSP-001 for different time. The cells were then fixed and stained with PI, and analyzed by flow cytometry. Percentages of cells in different phases were shown. The data are representative of three independent experiments. (C) MPSP-001 induced apoptosis with the cleavage of PARP. The time (left panel) and concentration (right panel) effects of MPSP-001 on cell apoptosis of HeLa cells. Protein samples were separated by SDS-PAGE for immunoblot analysis using antibody against PARP and GAPDH were stained as the internal cytosolic control.

free energy of binding was $-8.38 \mathrm{kcal} / \mathrm{mol}$. The hydroxyl groups of MPSP-001 form hydrogen bonds to the residues Leu 252 and Leu 255 of the $\beta$ tubulin with distances of $2.89 \AA$ and $2.88 \AA$, respectively. Additionally, the phenyl ring moieties of MPSP-001 are positioned towards Val 315 and Ala 316 of the $\beta$ tubulin, establishing hydrophobic contacts with the binding pocket (Figure 4C, 4D). The docking result, which has shown proper binding free energy and intermolecular interactions, shows a possible mode why MPSP-001 competes with colchicine.

\section{MPSP-001 exhibited potent synergistic effect in combination} with Taxol and colchicine

Before evaluating the interactions between MPSP-001 and 
A
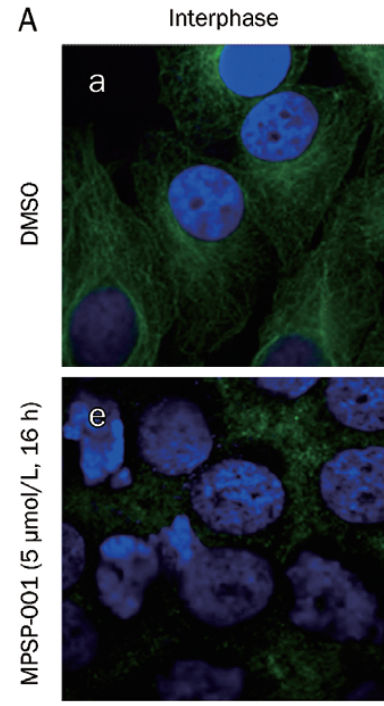

Tubulin disaggregation
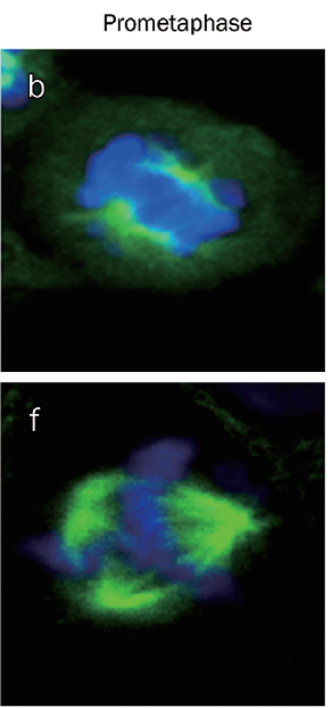

Tri-poles
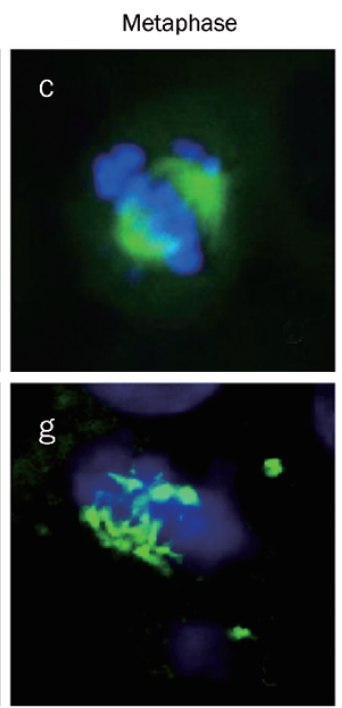

Multi-poles
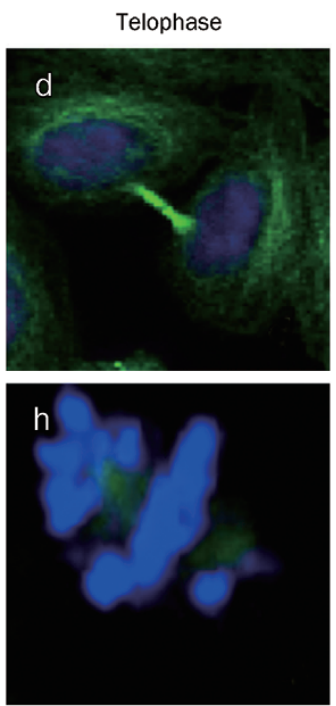

Chromosome misalignment

B

\begin{tabular}{lccc}
\hline & DMSO & MPSP-001 & P value \\
\hline Non-bipoles & $2 / 103(1.94 \%)$ & $39 / 435(8.97 \%)$ & 0.020 \\
Chromosome misalignment & $1 / 103(0.97 \%)$ & $27 / 435(6.21 \%)$ & 0.042 \\
\hline
\end{tabular}

C
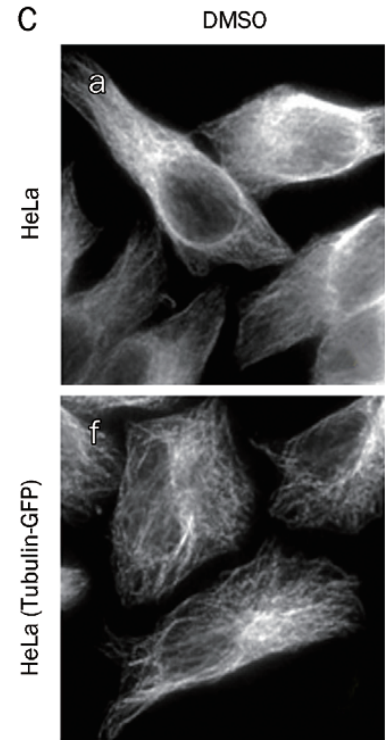

Taxol $(250 \mathrm{nmol} / \mathrm{L})$
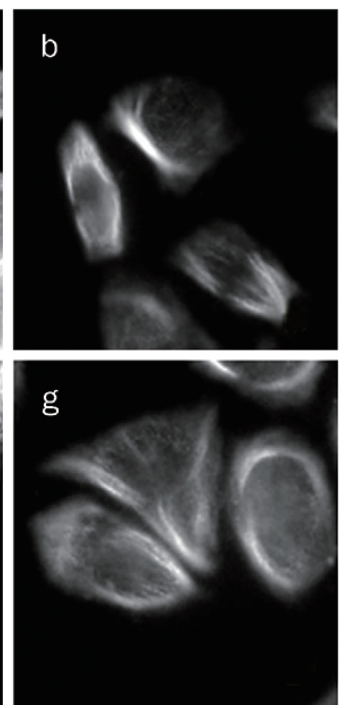

\section{Colchicine (100 nmol/L)}
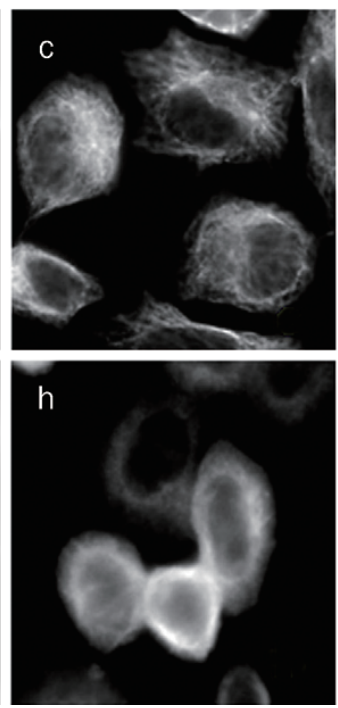

Vincristine $(100 \mathrm{nmol} / \mathrm{L})$
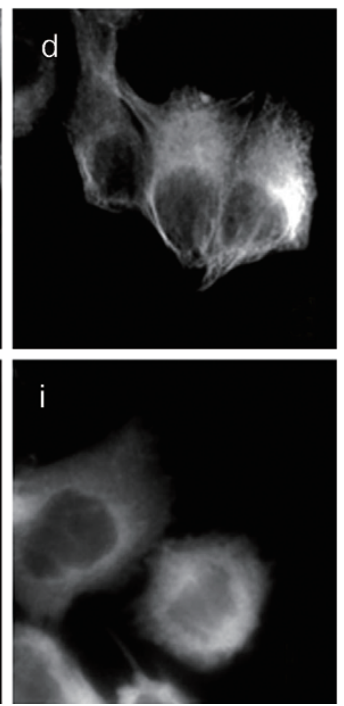

MPSP-001 (5 $\mu \mathrm{mol} / \mathrm{L})$
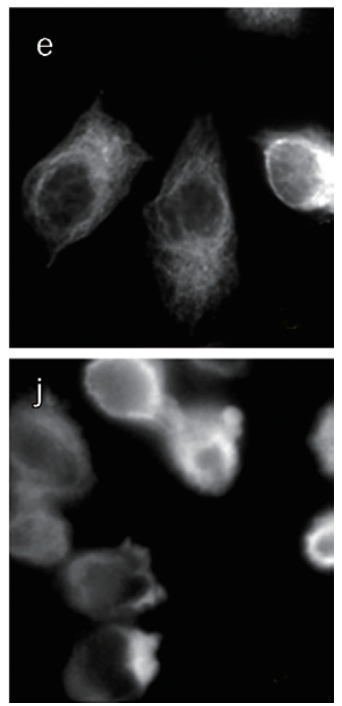

Figure 3. Effects of MPSP-001 on mitotic spindle formation and tubulin disruption. (A) Illustrations of the effects of MPSP-001 on the mitotic spindle in HeLa cells (e-h) using immuno-fluorescence microscopy technique. HeLa cells grown in log phase were treated with $5 \mu$ mol/L MPSP-001 for 16 h, followed by fixation and immunofluorescence staining for tubulin (white) and DNA (blue). Examples of a normal interphase (a), normal prometaphase (b), normal metaphase (c) and normal telophase (d) were shown. Examples of a damaged interphase (e) and various forms of abnormal mitoses include a tripolar prometaphase (f), a mutipolar metaphase (g) and an abnormal bipolar metaphase with lagging chromosomes or chromosomes not aligned to the metaphase plate $(\mathrm{h})$ were shown $(\times 600)$. (B) Statistical analysis of the effects of MPSP-001 on the mitotic spindles in HeLa cells. (C) Disruption of tubulin by MPSP-001, colchicine, and paclitaxel in HeLa cells and tubulin-GFP-HeLa cells (over-expression of the fusion protein of tubulin and GFP). HeLa cells and tubulin-GFP-HeLa cells grown in log phase were treated with 0.1\% DMSO (a, f), $250 \mathrm{nmol} / \mathrm{L} \mathrm{Taxol}$ (b, g), $100 \mathrm{nmol} / \mathrm{L}$ colchicine (c, h), 100 $\mathrm{nmol} / \mathrm{L}$ vincristine (d, i) and $5 \mu \mathrm{mol} / \mathrm{L}$ MPSP-001 for $16 \mathrm{~h}$, followed by fixation and immunofluorescence staining for tubulin (In Tubulin-GFP-HeLa cells, immunofluorescence staining was omitted). Then the morphology of interphase tubulin (white) was observed (×600). 
A

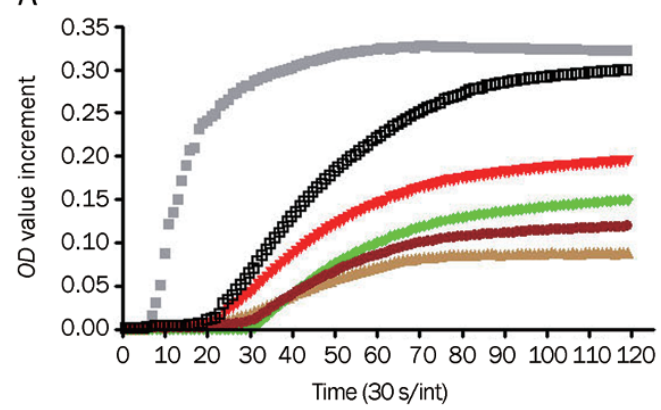

- Taxol $(10 \mu \mathrm{mol} / \mathrm{L})$

口 $\operatorname{DMSO}(0.1 \%)$

- MPSP-001 $(25 \mu \mathrm{mol} / \mathrm{L})$

- MPSP-001 (100 $\mu \mathrm{mol} / \mathrm{L})$

- Vincristine $(10 \mu \mathrm{mol} / \mathrm{L})$

- Colchicine $(10 \mu \mathrm{mol} / \mathrm{L})$
B

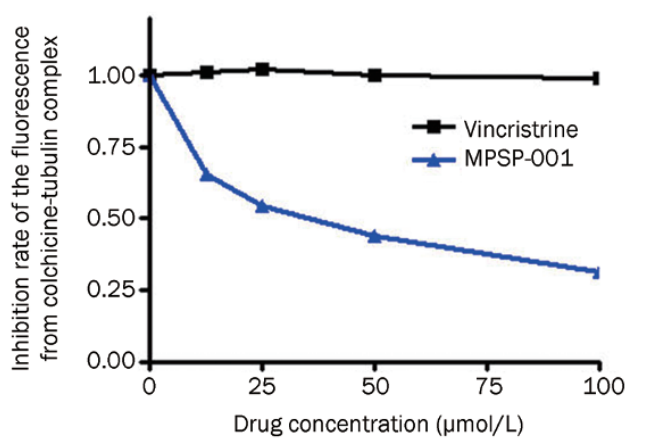

C

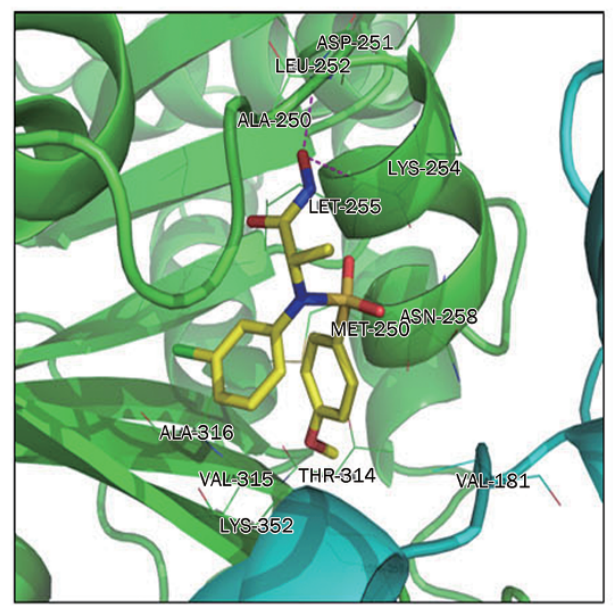

D

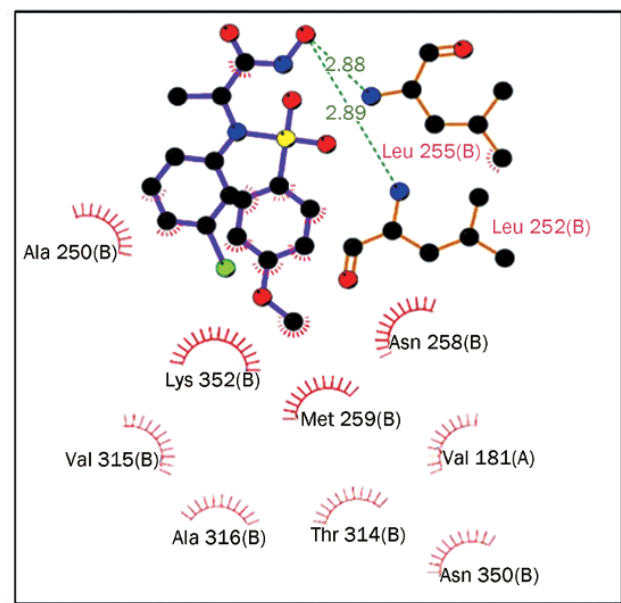

Figure 4. Effects of MPSP-001 on in vitro tubulin polymerization and competitive binding of colchicine site. (A) Effects of MPSP-001 (25 $\mu$ mol/L, 100 $\mu \mathrm{mol} / \mathrm{L})$, Taxol $(10 \mu \mathrm{mol} / \mathrm{L})$, colchicines $(10 \mu \mathrm{mol} / \mathrm{L})$ and vincristine $(10 \mu \mathrm{mol} / \mathrm{L})$ on bovine brain tubulin polymerization were measured turbidimetrically. Changes in absorbance at $340 \mathrm{~nm}$ (A340) were measured and plotted as a function of time. (B) MPSP-001 binding to tubulin directly and inhibiting tubulin polymerization. Tubulin was co-incubated with indicated concentrations of VCR and MPSP-001 for $1 \mathrm{~h}$, then $5 \mu \mathrm{mol} / \mathrm{L}$ colchicine was added. The fluorescence was measured by spectrofluorometer. All assays were repeated twice and representative data were shown. (C) Interactions between $\alpha, \beta$-tubulin and compound MPSP-001 in the docking complex in 3D pattern. Tubulin was shown in cartoon style with the $\beta$ and $\alpha$ subunit colored in green and cyan, respectively; compound MPSP-001 was shown in stick style; the residues within $4 \AA$ around compound MPSP-001 were shown in line style. Magenta dashed lines denoted the potential hydrogen bonds. (D) 2D representation were drawn using LIGPLOT. Dashed lines represented hydrogen bonds and spiked residues form hydrophobic contacts with the compound.

Taxol or colchicine, we calculated the $\mathrm{MB}_{50}$ value for each of the compounds. It represents the concentration of compounds that render $50 \%$ of the cells to be arrested in mitosis. As shown in Figure $5 \mathrm{~A}$, the $\mathrm{MB}_{50}$ value of Taxol, colchicine and MPSP-001 were 177.7 \pm 2.7 (nmol/L), $77.8 \pm 2.8(\mathrm{nmol} / \mathrm{L})$, and $2.9 \pm 0.4(\mu \mathrm{mol} / \mathrm{L})$, respectively. At concentrations lower than their $\mathrm{MB}_{50}$ values, either colchicine $(10 \mathrm{nmol} / \mathrm{L})+\mathrm{MPSP}-001$ $(1 \mu \mathrm{mol} / \mathrm{L})$ or Taxol $(25 \mathrm{nmol} / \mathrm{L})+\mathrm{MPSP}-001(1 \mu \mathrm{mol} / \mathrm{L})$ had synergism effects on arresting the Hela cells in $G_{2} / M$ phase (Figure 5B). The combination index (CI) value was then calculated. The combination of colchicine with MPSP-001 against HeLa cells resulted in a CI value of 0.27 . Similarly, the combination of Taxol with MPSP-001 resulted in a CI value of 0.87 (Table 2). These results demonstrated a synergy between MPSP-001 with other mitotic blockers in blocking mitosis. Moreover, we also found their synergistic effects on apoptosis

Table 2. Combination index values of COL+MPSP-001 and Taxol+MPSP-001 in HeLa cells.

\begin{tabular}{|c|c|c|c|c|c|c|c|c|}
\hline \multirow[t]{2}{*}{ Combination type } & \multirow{2}{*}{$\begin{array}{l}\text { Percent of } \\
\mathrm{G}_{2} / \mathrm{M}\end{array}$} & \multicolumn{2}{|c|}{$\mathrm{COL}(\mathrm{nmol} / \mathrm{L})$} & \multicolumn{2}{|c|}{ Taxol (nmol/L) } & \multicolumn{2}{|c|}{ MPSP-001 ( $\mu \mathrm{mol} / \mathrm{L})$} & \multirow{2}{*}{$\mathrm{Cl}$} \\
\hline & & $D_{1}$ & $(\mathrm{Dm})_{1}$ & $\mathrm{D}_{1}$ & $(\mathrm{Dm})_{1}$ & $\mathrm{D}_{2}$ & $(\mathrm{Dm})_{2}$ & \\
\hline MPSP-001+COL & $64.10 \%$ & 10.00 & 133.32 & NA & NA & 1.00 & 5.45 & 0.27 \\
\hline MPSP-001+Taxol & $41.70 \%$ & NA & NA & 25.00 & 105.70 & 1.00 & 1.95 & 0.87 \\
\hline
\end{tabular}

The $\mathrm{Cl}$ is calculated by the following equation: $\mathrm{Cl}=\mathrm{D}_{1} /(\mathrm{Dm})_{1}+\mathrm{D}_{2} /(\mathrm{Dm})_{2}+\mathrm{D}_{1} \times \mathrm{D}_{2} /\left[(\mathrm{Dm})_{1} \times(\mathrm{Dm})_{2}\right] . \quad \mathrm{Cl}>1$ indicates antagonism, $\mathrm{Cl}<1 \mathrm{indicates}$ synergy, and $\mathrm{Cl}=1$ indicates additivity. $\mathrm{COL}$,colchicines; $\mathrm{Cl}$, combination index; NA, Not Applicable. 
A
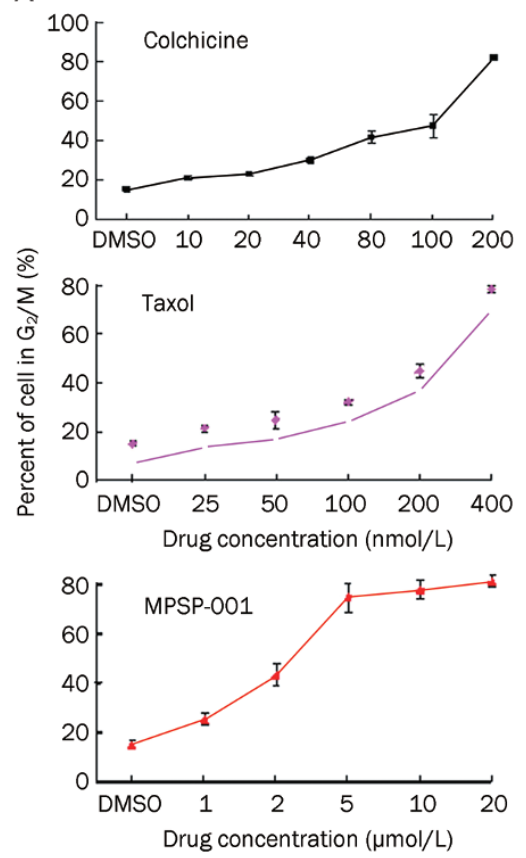

B
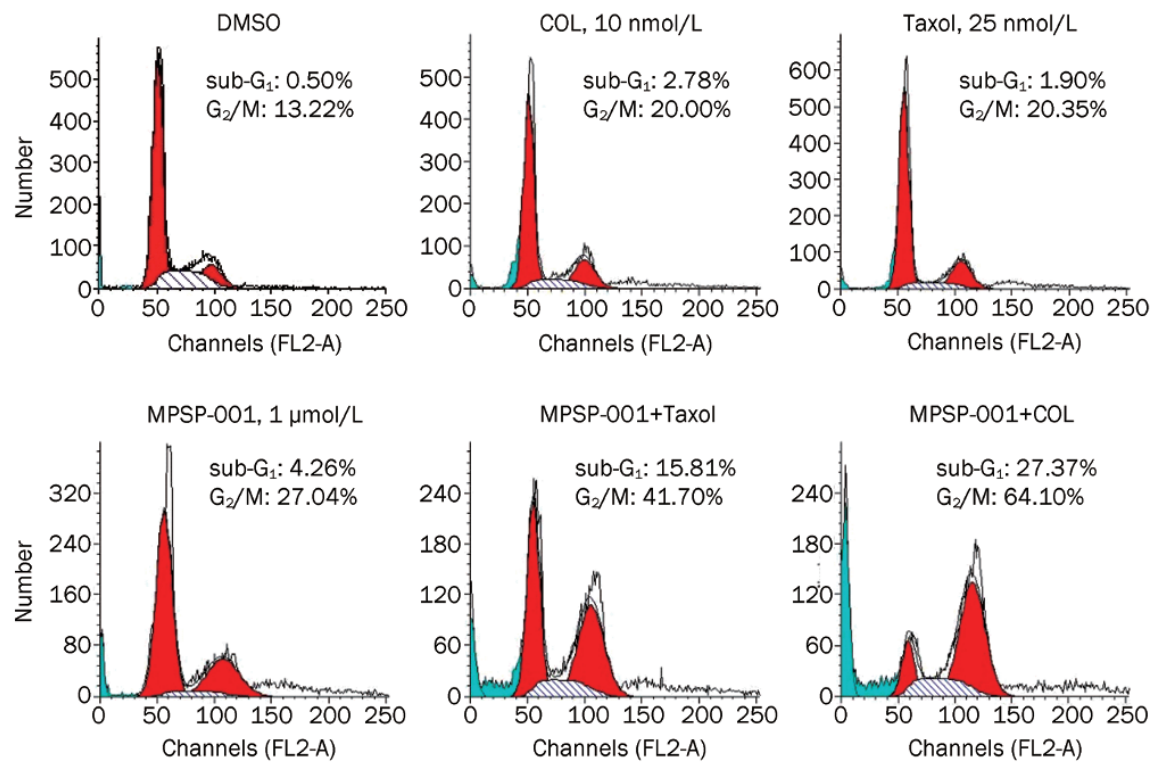

Figure 5. Synergistic effects of MPSP-001 in combination with colchicine and Taxol on blocking mitosis. (A) Flow cytometry analysis of the mitosis block effects using different concentrations of MPSP-001, colchicines and Taxol. HeLa cells were incubated with different concentrations of MPSP-001, colchicines and taxol for $16 \mathrm{~h}$. Then cells were fixed and stained with PI and analyzed by flow cytometry. The $\mathrm{G}_{2} / \mathrm{M}$ distribution values were graphed. Data are the means of triplicates \pm SD. (B) Flow cytometry analysis of the effects of taxol $(25 \mathrm{nmol} / \mathrm{L})$, colchicine $(10 \mathrm{nmol} / \mathrm{L}), \mathrm{MPSP}-001$ ( $1 \mu \mathrm{mol} / \mathrm{L})$ or the combination of Taxol+MPSP-001 and colchicines+MPSP-001 on cell cycle distribution. HeLa cells were incubated with drugs for $16 \mathrm{~h}$. The cells were then fixed and stained with PI and analyzed by flow cytometry.

with an additional accumulation of sub-G cells $^{[37]}$ (Figure $5 B$ ).

\section{MPSP-001 exhibited potent cytotoxicity against multidrug-} resistant cell lines

Multidrug resistance is a notorious nature of tumors for most naturally derived anticancer drugs ${ }^{[11]}$. To find out whether a major multidrug resistance mechanism, P-glycoprotein (P-gp) overexpression, influences the anti-cancer activity of MPSP001, we tested the effects of MPSP-001 on two pairs of tumor cell lines with different expression levels of P-gp-overexpression, KB/VCR and MCF-7/ADR. The P-gp-overexpression cells showed high degrees of drug resistance to the control compounds VCR and ADR (RF values were 110.2 and 50.2, respectively) (Table 3). For each of these cell lines, MPSP-001 displayed equal cytotoxicity towards the multidrug resistant cells as well as the corresponding parental cells, with RF values of 1.2 and 1.9 (Table 3). These data indicated that MPSP001 ' s anti-cancer activity is not affected by the P-gp pump.

\section{Discussion}

Microtubules are attractive targets for chemotherapeutic agents $^{[2]}$. We report here that a novel benzenesulfonamide derivative, MPSP-001, inhibits growth of a broad-spectrum of cancer cell lines at the micromolar range (Table 1). It caused cell cycle arrest at the $\mathrm{G}_{2} / \mathrm{M}$ phase and induced apoptosis of tumor cells. Further studies revealed that MPSP-001 disrupted

Table 3. Growth inhibition of MPSP-001 against drug-resistant cell lines.

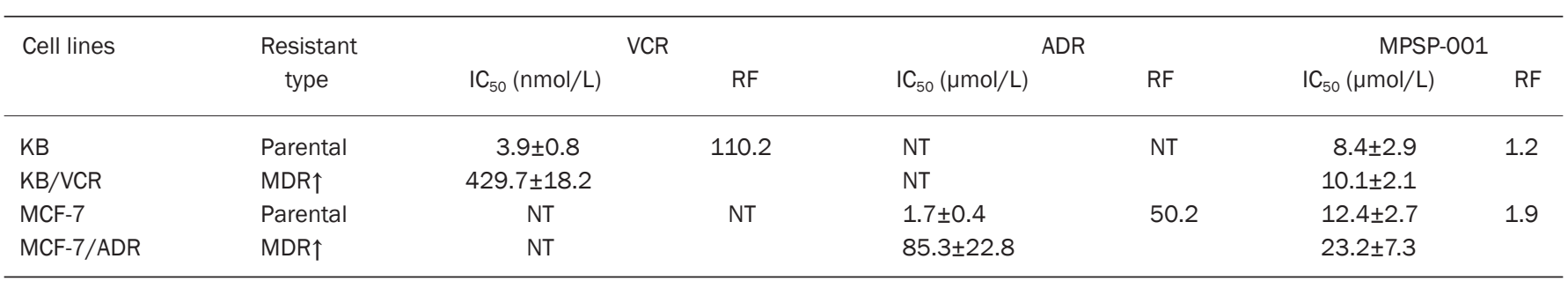

All resistant cell lines were maintained in drug-free medium for $3 \mathrm{~d}$ before seeding for growth inhibition assay. Each value represented the mean \pm SD. of three independent experiments. The RF was calculated as the ratio of the $\mathrm{IC}_{50}$ value of the multidrug-resistant cells to that of the corresponding sensitive parental cells. VCR, vincristine; ADR, adriamycin; RF, resistant fold; NT, not tested. 
mitotic spindles by inhibiting microtubule polymerization. The exact mechanism by which MPSP-001 inhibited microtubule polymerization and induced apoptosis is not completely understood. Visualization of mitotic spindle with fluorescent microscopy demonstrated that MPSP-001 caused non-bipolar mitotic spindles with chromosome misalignment. The modes of action on inhibiting microtubule polymerization and the effects on mitotic spindle formation of MPSP-001 resemble that of colchicine. We further performed in vitro fluorometric experiment to test whether MPSP-001 can displace colchicine from tubulin, which concluded that MPSP-001 can bind to colchicine site of tubulin. Moreover, molecular docking predicts that MPSP-001 can form two hydrogen bonds to the residues Leu252 and Leu255 of the $\beta$ tubulin and establish hydrophobic contacts with the colchicine binding pocket (Figure 4C, $4 \mathrm{D})$.

Drug resistance is a serious problem that restricts the use of microtubule-interfering drugs for clinical therapy ${ }^{[38]}$. MPSP001 exerts a similar potency, regardless of the cell's MDR or MRP status (Table 3), suggesting that it is not a substrate of the efflux pumps.

Drugs often have more than one target. For exemple, another sulfonamide, HMN-214, its antitumor activity is mediated by the inhibiting of polo-like kinase and NF-Y $\mathrm{Y}^{[23-25]}$. S9, a novel anticancer agent, exerts its anti-proliferative activity by interfering with both PI3K-Akt-mTOR signaling and microtubule cytoskeleton ${ }^{[28]}$. Likely, the fact that MPSP-001 acted synergistically with colchicine and taxol on blocking mitosis and inducing apoptosis suggests that MPSP-001 may interact with other targets involved in spindle checkpoint or cell death.

Although its targets and mechanisms remain unclear, MPSP-001 exhibits synergistic effects with colchicine and taxol on blocking mitosis and inducing apoptosis, as well as its ability to overcome P-glycoprotein mediated multidrug resistance in taxanes and vinca alkaloids-resistant tumor cells. These results reveal its potentials in anticancer therapy.

In conclusion, our data provide compelling evidences that the novel sulfonamide-based compound, MPSP-001, has broad-spectrum anti-tumor efficacy in vitro by triggering tumor cell apoptosis and is effective against drug resistant tumor cells. Our study indicates that MPSP-001 is a novel microtubule depolymerizer and mitotic blocker. The indepth studies on sulfonamides will help us to design better anti-cancer drugs.

\section{Acknowledgements}

This work was supported by the National Natural Science Foundation of China (Grant 30672481, 30771097, 90713029, and 30828018); the Shanghai Science and Technology Research Grant (08DZ1971403); the China Ministry of Science and Technology Research Grant (2008ZX10002-020); and the National Science \& Technology Major Project "Key New Drug Creation and Manufacturing Program", China (Number: 2009ZX09301001 and 2009ZX09103-064).

We thank Hai-tian QUAN, Xiu-quan MA and Yan-xin CUI for their kindly help.

\section{Author contribution}

Qiang YU and Zu-long LIU designed research; Zu-long LIU, Wei TIAN, Yong WANG, and Shan KUANG performed research; Qiang YU and Xiao-min LUO contributed reagents and analytic tools; Qiang YU and Zu-long LIU analyzed data; $\mathrm{Zu}$-long LIU wrote the paper.

\section{References}

1 Urruticoechea A, Alemany R, Balart J, Villanueva A, Vinals F, Capella G. Recent advances in cancer therapy: an overview. Curr Pharm Des 2010; 16: 310.

2 Dumontet C, Jordan MA. Microtubule-binding agents: a dynamic field of cancer therapeutics. Nat Rev Drug Discov 2010; 9: 790-803.

3 Gan PP, McCarroll JA, Po'uha ST, Kamath K, Jordan MA, Kavallaris M. Microtubule dynamics, mitotic arrest, and apoptosis: drug-induced differential effects of betalll-tubulin. Mol Cancer Ther 2010; 9: 1339-48.

4 Screpanti E, Santaguida S, Nguyen T, Silvestri R, Gussio R, Musacchio A, et al. A screen for kinetochore-microtubule interaction inhibitors identifies novel antitubulin compounds. PLoS One 2010; 5: e11603.

5 Kanthou C, Tozer GM. Microtubule depolymerizing vascular disrupting agents: novel therapeutic agents for oncology and other pathologies. Int J Exp Pathol 2009; 90: 284-94.

6 Bhalla KN. Microtubule-targeted anticancer agents and apoptosis. Oncogene 2003; 22: 9075-86.

7 Li CM, Lu Y, Ahn S, Narayanan R, Miller DD, Dalton JT. Competitive mass spectrometry binding assay for characterization of three binding sites of tubulin. J Mass Spectrom 2010; 45: 1160-6.

8 Liou JP, Hsu KS, Kuo CC, Chang CY, Chang JY. A novel oral indolinesulfonamide agent, N-[1-(4-methoxybenzenesulfonyl)-2,3-dihydro$1 \mathrm{H}$-indol-7-yl]-isonicotinamide (J30), exhibits potent activity against human cancer cells in vitro and in vivo through the disruption of microtubule. J Pharmacol Exp Ther 2007; 323: 398-405.

9 Wall ME, Wani MC. Camptothecin and taxol: from discovery to clinic. J Ethnopharmacol 1996; 51: 239-53; discussion 53-4.

10 Dumontet $\mathrm{C}$, Sikic BI. Mechanisms of action of and resistance to antitubulin agents: microtubule dynamics, drug transport, and cell death. J Clin Oncol 1999; 17: 1061-70.

11 Gottesman MM. Mechanisms of cancer drug resistance. Annu Rev Med 2002; 53: 615-27.

12 Hansch C. Comparative QSAR of the sulfonamide function. Farmaco 2003; 58: 625-9.

13 Crespo R, de Bravo MG, Colinas PA, Bravo RD. In vitro antitumor activity of N-glycosyl sulfonamides. Bioorg Med Chem Lett 2010; 20: 6469-71.

14 Owa T, Yoshino H, Okauchi T, Yoshimatsu K, Ozawa Y, Sugi NH, et al. Discovery of novel antitumor sulfonamides targeting G1 phase of the cell cycle. J Med Chem 1999; 42: 3789-99.

15 Yamada Y, Yamamoto N, Shimoyama T, Horiike A, Fujisaka Y, Takayama K, et al. Phase I pharmacokinetic and pharmacogenomic study of E7070 administered once every 21 days. Cancer Sci 2005; 96: 721-8.

16 Smyth JF, Aamdal S, Awada A, Dittrich C, Caponigro F, Schoffski P, et al. Phase II study of E7070 in patients with metastatic melanoma. Ann Oncol 2005; 16: 158-61.

17 Baur M, Gneist M, Owa T, Dittrich C. Clinical complete long-term remission of a patient with metastatic malignant melanoma under therapy with indisulam (E7070). Melanoma Res 2007; 17: 329-31.

18 Ozawa Y, Sugi NH, Nagasu T, Owa T, Watanabe T, Koyanagi N, et al. E7070, a novel sulphonamide agent with potent antitumour activity in 
vitro and in vivo. Eur J Cancer 2001; 37: 2275-82.

19 Iwamoto Y, Nishio K, Fukumoto H, Yoshimatsu K, Yamakido M, Saijo N. Preferential binding of E7010 to murine beta 3-tubulin and decreased beta 3-tubulin in E7010-resistant cell lines. Jpn J Cancer Res 1998; 89: 954-62.

20 Yamamoto K, Noda K, Yoshimura A, Fukuoka M, Furuse K, Niitani H. Phase I study of E7010. Cancer Chemother Pharmacol 1998; 42: 127-34.

21 Yoshimatsu K, Yamaguchi A, Yoshino H, Koyanagi N, Kitoh K. Mechanism of action of E7010, an orally active sulfonamide antitumor agent: inhibition of mitosis by binding to the colchicine site of tubulin. Cancer Res 1997; 57: 3208-13.

22 Dittrich C, Dumez H, Calvert H, Hanauske A, Faber M, Wanders J, et al. Phase I and pharmacokinetic study of E7070, a chloroindolylsulfonamide anticancer agent, administered on a weekly schedule to patients with solid tumors. Clin Cancer Res 2003; 9: 5195-204.

23 Garland LL, Taylor C, Pilkington DL, Cohen JL, Von Hoff DD. A phase I pharmacokinetic study of HMN-214, a novel oral stilbene derivative with polo-like kinase-1-interacting properties, in patients with advanced solid tumors. Clin Cancer Res 2006; 12: 5182-9.

24 Tanaka H, Ohshima N, Ikenoya M, Komori K, Katoh F, Hidaka H. HMN176 , an active metabolite of the synthetic antitumor agent HMN-214, restores chemosensitivity to multidrug-resistant cells by targeting the transcription factor NF-Y. Cancer Res 2003; 63: 6942-7.

25 Takagi M, Honmura T, Watanabe S, Yamaguchi R, Nogawa M, Nishimura I, et al. In vivo antitumor activity of a novel sulfonamide, $\mathrm{HMN}-214$, against human tumor xenografts in mice and the spectrum of cytotoxicity of its active metabolite, HMN-176. Invest New Drugs 2003; 21: 387-99.

26 Brady AJ, Kearney P, Tunney MM. Comparative evaluation of 2,3-bis [2-methyloxy-4-nitro-5-sulfophenyl]-2H-tetrazolium-5-carboxanilide (XTT) and 2-(2-methoxy-4-nitrophenyl)-3-(4-nitrophenyl)-5-(2,4-disulfophenyl)-2H-tetrazolium, monosodium salt (WST-8) rapid colorimetric assays for antimicrobial susceptibility testing of staphylococci and ESBL-producing clinical isolates. J Microbiol Methods 2007; 71: 30511.

27 Kuo CC, Hsieh HP, Pan WY, Chen CP, Liou JP, Lee SJ, et al. BPROL075, a novel synthetic indole compound with antimitotic activity in human cancer cells, exerts effective antitumoral activity in vivo. Cancer Res 2004; 64: 4621-8.
28 Zhang C, Yang N, Yang CH, Ding HS, Luo C, Zhang Y, et al. S9, a novel anticancer agent, exerts its anti-proliferative activity by interfering with both PI3K-Akt-mTOR signaling and microtubule cytoskeleton. PLoS One 2009; 4: e4881.

29 Ravelli RB, Gigant B, Curmi PA, Jourdain I, Lachkar S, Sobel A, et al. Insight into tubulin regulation from a complex with colchicine and a stathmin-like domain. Nature 2004; 428: 198-202.

30 Morris GM, Goodsell DS, Halliday RS, Huey R, Hart WE, Belew RK, et al. Automated docking using a Lamarckian genetic algorithm and an empirical binding free energy function. J Comput Chem 1998; 19 : 1639-62.

31 Chou TC. Drug combination studies and their synergy quantification using the Chou-Talalay method. Cancer Res 2010; 70: 440-6.

32 Rodea-Palomares I, Petre AL, Boltes K, Leganes F, Perdigon-Melon JA, Rosal R, et al. Application of the combination index (Cl)-isobologram equation to study the toxicological interactions of lipid regulators in two aquatic bioluminescent organisms. Water Res 2010; 44: 42738.

33 Kodama M, Murakami M, Kodama T. Statistical analysis of the ageadjusted incidence rates of human neoplasias: changes in time and space from early 1960's to mid 1980's with special reference to the steroid criminal hypothesis of carcinogenesis. Int J Mol Med 1999; 3: 435-41.

34 Yoshida D, Hoshino S, Shimura T, Takahashi H, Teramoto A. Druginduced apoptosis by anti-microtubule agent, estramustine phosphate on human malignant glioma cell line, U87MG; in vitro study. J Neurooncol 2000; 47: 133-40.

35 Leoni LM, Hamel E, Genini D, Shih H, Carrera CJ, Cottam HB, et al. Indanocine, a microtubule-binding indanone and a selective inducer of apoptosis in multidrug-resistant cancer cells. J Natl Cancer Inst 2000; 92: 217-24.

36 Bhattacharyya B, Wolff J. Promotion of fluorescence upon binding of colchicine to tubulin. Proc Natl Acad Sci U S A 1974; 71: 2627-31.

37 Darzynkiewicz Z, Juan G, Li X, Gorczyca W, Murakami T, Traganos F. Cytometry in cell necrobiology: analysis of apoptosis and accidental cell death (necrosis). Cytometry 1997; 27: 1-20.

38 Shibayama Y, Nakano K, Maeda H, Taguchi M, Ikeda R, Sugawara $\mathrm{M}$, et al. Multidrug resistance protein 2 implicates anticancer drugresistance to sorafenib. Biol Pharm Bull 2011; 34: 433-5. 